\title{
EMPOWERMENT OR IMPOVERISHMENT OF CHILDREN FROM SOCIAL NETWORKS? PERCEPTIONS OF SEXUALIZED IMAGES OF GIRLS IN INSTAGRAM
}

\author{
¿Empoderamiento o empobrecimiento de la infancia \\ desde las redes sociales? Percepciones de las \\ imágenes de niñas sexualizadas en Instagram
}

Mónica Díaz-Bustamante-Ventisca and Carmen Llovet-Rodríguez

Nota: Este artículo se puede leer en español en:

http://www.elprofesionaldelainformacion.com/contenidos/2017/ene/08_esp.pdf

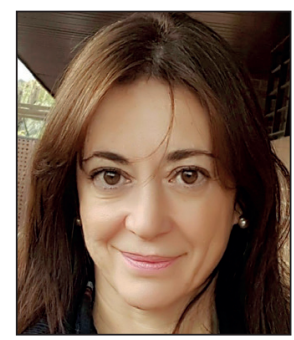

Mónica Díaz-Bustamante-Ventisca holds a PhD in Business and Economics from the Complutense University of Madrid (UCM) and is associate professor there and at Villanueva University Center. She also contributes to masters' and other postgraduate courses in other institutions. A member of Villanueva-OCS research group, she has written book chapters and articles for peer-reviewed journals in Spain and abroad. She has also worked as marketing director for L'Oréal, Shiseido, and Chantelle.

http://orcid.org/0000-0002-8256-0209

Universidad Complutense de Madrid, Facultad de Ciencias de la Información Av. Complutense, s/n. 28040 Madrid, Spain mdiaz-bu@ucm.es

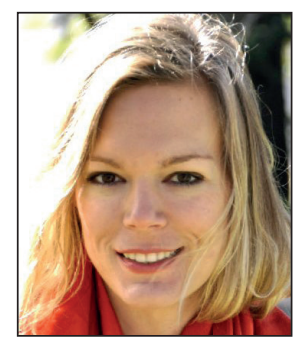

Carmen Llovet-Rodríguez is associate professor at the College of Arts and Sciences of the Beijing campus of the New York Institute of Technology. She holds a PhD from the Navarra University and has been a visiting scholar at the College of Mass Communication and Media Arts of Southern Illinois University, and the Department of Business Management of Glasgow Caledonian University as part of the Fashion, Marketing, and Retailing Group. A fashion journalist with Aceprensa, she has developed her teaching career in the teaching of public relations. Her research focuses on visual merchandising in fashion retailing and the impact of the beauty and fashion industries on women and children.

http://orcid.org/0000-0002-7743-9332

Faculty of International Media of Communication, University of China (ICUC) $3^{\text {rd }}$ Floor, Headquartes of Media Elite, Cultural and Creative Park of CUC № 10 Gaojingjia, Chaoyang District, Beijing, P.R. China cllovet@nyit.edu

Abstract

Although the phenomenon of the sexualization of children has prompted numerous investigations in recent years, very few have studied how adults perceive it, and none has studied the sexualization of girls in photographs in social networks. This work demonstrates, from the results of a structured online survey of 353 people, that the sexualization of girls in social networks generates perceptions that undervalue girls in intellectual, social, and moral aspects. Such perceptions depend on media consumption level, degree of self-objectification, and people's religiosity.

\section{Keywords}

Sexualization of children; Social networks; Digital empowerment; Perceptions of the sexualization of girls; Media consumption; Self-objectification; Religiosity; Instagram.

\section{Resumen}

Aunque el fenómeno de la sexualización infantil ha motivado numerosas investigaciones durante los últimos años, muy pocas han estudiado cómo lo perciben los adultos, y ninguna lo ha estudiado a partir de las impresiones que provocan las 
fotografías de niñas sexualizadas en las redes sociales. A partir de los resultados de una encuesta estructurada en internet a 353 personas, este trabajo demuestra que el aspecto sexualizado de las niñas en las redes sociales genera percepciones que las minusvaloran intelectual, social y moralmente. Dichas percepciones dependen del consumo de medios, del grado de auto-cosificación y de la religiosidad de las personas.

\section{Palabras clave}

Sexualización infantil; Redes sociales; Empoderamiento digital; Percepciones de niñas sexualizadas; Consumo de medios; Auto-cosificación; Religiosidad; Instagram.

Díaz-Bustamante-Ventisca, Mónica; Llovet-Rodríguez, Carmen (2017). “Empowerment or impoverishment of children from social networks? Perceptions of sexualized images of girls in Instagram". El profesional de la información, v. 26, n. 1, pp. 77-87.

https://doi.org/10.3145/epi.2017.ene.08

\section{Introduction}

In 2007 the American Psychological Association (APA) published a report on the sexualization of girls in the context of the growing influence of American culture on the sexualization of children. This report defined the concept of the sexualization of girls, presented many of its negative effects, and encouraged further research on this phenomenon: its frequency and possible growth, circumstances and factors that favor or hinder it, its presence in different formats and media, its relation to other concepts related to inappropriate age development (e.g. child adultization), and its existence and effects in different countries and cultures, etc.

Thus, in recent years many studies have been carried out in this area mainly in order:

- to expose the spread of images that sexualize girls in the media (Goodin et al., 2011; Hall; West; Mclntyre, 2012; Graff; Murnen; Krause, 2013);

- to show the negative effects of the sexualization of children (Lamb, 2009; Bailey, 2011; Daniels; Zurbriggen, 2016);

- explore factors that may influence girls' self-sexualization (Starr; Ferguson, 2012).

However, exposure and criticism about the sexualization of children has generated an opposing trend which brands the former movement as reductionist and monolithic (Egan; Hawkes, 2008) and the new trend aims to promote the health and sexual rights of children (Lerum; Dworkin, 2009).

In this context, it is important to note that the subjects' perceptions of the different phenomena vary according to their socio-economic, cultural, demographic, geographical, and psychographic characteristics (Dietrich et al., 2015; Wills et al., 2015, Schuster; Kubacki; Rundle-Thiele, 2015), and thus the following questions arise:

- Are perceptions of the sexualization of girls in the media likely to vary according to the profiles of the people who see them? If so, what variables determine greater or lesser sensitivity to this phenomenon?

- Are the perceptions of images that sexualize girls in social networks detrimental to such girls? And if they are, in what ways specifically?

This study seeks to respond to these questions in the specific case of images that sexualize girls on Instagram, a social network.

\section{The state of the question}

\subsection{The concept of child sexualization}

The APA report (2007) holds that the "sexualization" occurs when at least one of the following actions takes place:

1) a person's value is reduced to their sexual attractiveness or behavior;

2) physical attractiveness is equated with being sexy;

3) a person is represented as an object and not as a person with freedom of action and decision;

4) sexuality is inappropriately imposed on a person.

Arteaga-Villamil (2010) focuses on "child sexualization" in girls by defining it as "the way in which female adolescents, within their social context, show certain facets which are not their own, such as the excessive femininity derived from sexual loading".

In the UK, The Bailey Report (2011) introduces the concept of "child hyper-sexualization" and defines it as "the excessively precocious sexualization of expressions, attitudes, or dress codes".

Finally Llovet-Rodríguez, Díaz-Bustamante, and PatiñoAlves (2016) have found that the expression "childhood sexualization" in Spanish is confusing for some people who relate it to the gender identity of boys and girls, and thus they prefer to use the term "childhood adultization" (or "childhood eroticization") to describe children who appear to be older than they actually are by exhibiting attributes that make them sexually attractive to other people.

\subsection{Effects of childhood sexualization}

"Childhood sexualization" is also known for the negative effects it can have on children and especially on girls (MiIwood, 2006; APA, 2007; Ortiz-Tardio, 2009; Machia; Lamb, 2015; Bailey, 2011; Serrano, 2013; Acosta, 2014; Albéniz, 2014).

Thus, the APA (2007) points out the following consequences of a girl being sexualized and/or is sexualized in appearance:

1) focusing on physical appearance as the main source of acceptance decreases a girl's cognitive abilities and leads to lost opportunities; 
2) a passive role may be adopted by the child;

3) it negatively influences their perception of their virginity and sexual relations (risk factors in premature pregnancy, abortions, and transmission of sexual diseases);

4 ) it influences their relationships with other girls with regard to competing for boys and leads to the rejection of girls who do not fit into the ideal of beauty; and

5) it influences the view they have about going out with boys, encourages sexual harassment, and sexual violence of boys towards girls.

Rodríguez (2007) adds the pernicious effects of the eroticization of girls who place themselves in a position of inferiority by reducing their own value to their capacity for sexual attraction.

The Bailey Report (2011) warns that the hyper-sexualization of girls makes them a sexual object at a very early stage by encouraging them to adopt sexually stereotyped roles and behaviors that do not correspond to their age (Serrano, 2013).

\section{The hyper-sexualization of girls makes them a sexual object at a very early sta- ge by encouraging them to adopt sexua- lly stereotyped roles and behaviors that do not correspond to their age}

\begin{abstract}
Albéniz (2014), for his part, holds that the early sexualization of girls influences both the adoption of inappropriate behaviors and promotes an exaggerated interest in their physical appearance in order to emulate successful actresses and models. The same author calls this the "pathological eroticization of childhood" and warns of the risks involved: children can suffer physical and psychological problems in the medium and long term such as eating disorders.
\end{abstract}

However, in contrast to previous positions, there are others that not only cast doubt on whether child sexualization has negative effects on children, but also assert that it can have positive effects. Egan and Hawkes (2008) hold that the protection of children's innocence may serve racist, sexist, or homophobic interests and that the culture in which children are viewed as sexual citizens should be directed towards a positive view of sex as an integral part of their daily lives. In the same vein Lerum and Dworkin (2009) conclude that sexualization can have positive or negative effects depending on the particular institutional, cultural, and interpersonal context in which it occurs.

\subsection{Factors which favor child sexualization: media and mothers}

According to the APA (2007) the two main factors that motivate child sexualization are media consumption by the children and the influence of their mothers on them. In the view of some expert psychologists and sociologists, the fact that girls reproduce images or behaviors inconsistent with their age is a result of the following factors:
- non-compliance with the child protection broadcasting schedule by the media;

- the content of magazines, programs, and television series for adolescents;

- the stereotypes of girls and adolescents promoted through music videos and the internet;

- trends in children's fashion; and

- the influence of mothers (Corisco; Pérez-Hernando, 2014).

Serrano (2013) also points out that advertising, the fashion industry, TV series, and children's programs and some video clips as sources of children's hyper-sexualization. In these cases, referring to hyper-sexualization is appropriate because an adult image of children is projected (especially for girls) or because girls are encouraged to copy young adolescents in their clothing, makeup, hairstyle, etc., or to copy the less exemplary behavior of children's idols. In all these cases the transition from childhood to adolescence is accelerated at a time when children are neither physically nor psychologically prepared for it, which can lead to health damage and disorders.

A study by Graff, Murnen, and Krause (2013), highlights the increase in the sexualizing of girls in the adolescent magazine "Seventeen" and the magazine for children "Girl's Life" (from 1994 through 2011 in the United States). The authors conclude that these images put a limitation on girls' concept of themselves.

As for the relationship between advertising and child sexualization, many voices warn of the harmful exposure of children to early sexualized models in advertising or how the incessant sexualization of childhood in commercial communications can contribute to pathological sexual behaviors, including sexual abuse, pedophilia, and prostitution (Levin; Kilbourne, 2009, cited in ICMedia, 2011).

\section{Mothers who have a more objectified view of themselves predispose their daughters to that same vision and prefer a more sexualized physical appearance}

The fashion industry also seems to encourage the buying of a type of clothing and the production of a lifestyle that is not appropriate for children (Bailey, 2011; Graff; Murnen; Smolak, 2012). Furthermore, an increase in the supply of clearly sexualized girls' clothing and its influence on the development of a self-objectified vision of themselves has also been confirmed (Goodin et al., 2011). Thus, Euromonitor (2015) highlights the rise of a "mini-me" trend by which mothers and daughters dress alike.

Indeed, another of the fundamental causes of child sexualization is the influence of women on their children (APA, 2007; Bailey, 2011). As indicated by Starr y Ferguson (2012) mothers transfer to their daughters a stereotype of physical beauty that can influence their sexualization, so that mothers who have a more objectified view of themselves predispose their daughters to that same vision and prefer a more sexualized physical appearance. 
In this respect, it is worth noting that certain public administrations, organizations, media, and social networks have had to alert parents about the dangers of posting photos of their children on the Internet (AEPD, 2008; Fominaya; Peraita, 2013; Molina, 2015).

In contrast to the previous factors favoring child sexualization, Starr y Ferguson (2012) point out that parental (and, more specifically, maternal) mediation of children's consumption of media and family values and beliefs (especially religious) can moderate the early sexualization of children.

\subsection{Features which sexualize or infantilize girls}

Based on a list of sexualizing clothes items and accessories developed by Goodin et al. (2011; in Graff; Murnen; Krause, 2013), Graff, Murnen, and Krause (2013) have created a scale for determining whether or not representations of girls in the magazines specifically aimed at them sexualize them. This scale gathers features related to girls' clothing, footwear, hair, and hairstyle. One group brings together those characteristics which are sexualizing in nature, and the other those with an infantilizing effect. According to the authors, they take into account infantilizing characteristics due to the fact that the clothing that sexualizes the girls is usually combined with elements that infantilize them, both to disguise an excessively grotesque sexualization which might generate rejection by the parents, and to reproduce the infantilization which is often used to represent adult women and is also reflected in certain fashion styles.

Certain public administrations, organizations, media, and social networks have had to alert parents about the dangers of posting photos of their children on the Internet

\subsection{Perceptions of the sexualizion of women and girls}

Although there are numerous studies on the impact of sexual "objectification ${ }^{1 \text { " }}$ of women and girls on their selfperception and psychological well-being (Bartky, 1990; Fredrickson; Roberts, 1997) there have been very few studies that have looked at the perception of the sexualization of women and girls by third parties (Daniels; Zurbriggen, 2016).

Various authors (such as Cikara; Eberhardt; Fiske, 2011, or Daniels, 2012) have found that women with a sexualized appearance shown in the media are perceived by audiences to be less competent, resolute, intelligent, decorous and human, and more experienced sexually.

In this vein, Graff, Murnen, and Smolak (2012) have shown that 10 and 11 year-old girls dressed in a sexualized fashion are also perceived and valued as less competent, intelligent, resolute, capable, and decorous than girls who dress in an infantilized way or who do not dress in a sexualized way. To this aim, they carried out an experimental study in which the subjects (university students) evaluated photographs of girls whose clothing had been deliberately manipulated to show both sexually explicit and infantilized styles as well as more ambiguous or mixed ones.

Finally, Daniels and Zurbriggen (2016) have also verified through an experimental study with manipulated images that women whose Facebook profile shows photos with a sexualized appearance are rated by other women and girls as less competent and sociable than those whose Facebook profile does not show photos with a sexualized appearance.

However, despite the increase in the use of social networks in general and of emerging networks like Instagram, Pinterest, and Snapchat in particular $(I A B, 2016)$, there are no studies on the way in which real images that sexualize girls in these social networks are perceived by the adult public.

Women whose Facebook profile shows photos with a sexualized appearance are rated as less competent and sociable than those whose profile does not show photos with a sexualized appearance

\section{Objectives and method}

Based on the literature review set out above, the following research hypotheses are proposed:

$\mathrm{H} 1$ : The perceptions that adults have of the girls' sexualization in social networks are related to their media consumption.

H2: The perceptions that adults have of the girls' sexualization in social networks are related to their degree of "selfobjectification"'.

H3: The perceptions that adults have of the girls' sexualization in social networks are related to their religiosity.

H4: Girls who present themselves as sexualized in social networks are perceived by adults as less competent, intelligent, sociable and, decorous than non-sexualized ones.

The general objective of the empirical investigation is derived from these hypotheses: to analyze how photographs that sexualize girls spread through social networks are perceived by the adult public. The focus of this research is on girls alone (and not on girls and boys) due to the fact that most of the literature on which the above hypotheses are based exclusively concerns the sexualization of women and/ or girls. That is to say, the literature review does not allow for extending the hypotheses presented to the perceptions that adults have of children in general. The previous general objective can be broken down into the following specific objectives:

- To determine if the way in which the adults perceive images that sexualize girls in social networks is significantly related to their religiosity, their media consumption, and their level of self-objectification.

- To compare how the sexualization of girls is perceived in social networks, vis-à-vis non-sexualized girls, in terms of characteristics that measure their competence, intelligence, sociability, decorum, physical appearance, and clothing. 
- To determine the profile of the perceived image of sexualized and non-sexualized girls in social networks.

\section{Method}

The empirical research that supports this work is basically quantitative in nature. A structured survey was conducted over the Internet with 353 people who are residents in Spain (86\% in the Madrid province). We used a convenience sampling method, more specifically snowball sampling starting from the authors' personal connections. Table 1 summarizes the data that makes up the profile of the respondents.

The survey was conducted during the month of June, 2016.

The following scales and items were applied in the questionnaire used:

-To measure the perceived image of sexualized and non-sexualized girls whose photographs are spread in social networks, attributes from the McCroskey and McCain scale (1974) used by Daniels and Zurbriggen (2016) and attributes used in previous studies by Gurung and Chrouser (2007) and by Graff, Murnen, and Smolak (2012) were used. Because these attributes were generated to be used in English and to measure perceptions of adult women, the attributes used in this study (see Table 2) have been adapted to the Spanish language and the
Table 1. Socio-demographic and economic profile of the respondents. Data in \%

\begin{tabular}{|l|r|}
\hline \multicolumn{2}{|c|}{ Sex } \\
\hline Female & 75.3 \\
\hline Male & 24.7 \\
\hline
\end{tabular}

\begin{tabular}{|l|r|}
\hline \multicolumn{2}{|c|}{ Age } \\
\hline $18-25$ & 13.6 \\
\hline $26-30$ & 7.6 \\
\hline $31-35$ & 13.2 \\
\hline $36-40$ & 22.7 \\
\hline $41-50$ & 28.7 \\
\hline $51-60$ & 11.6 \\
\hline Over 60 & 2.0 \\
\hline Da & 0.8 \\
\hline
\end{tabular}

\begin{tabular}{|l|r|}
\hline \multicolumn{2}{|c|}{ Education } \\
\hline Primary & 5.2 \\
\hline Secondary & 14.3 \\
\hline University & 49.4 \\
\hline Post-graduate & 22.3 \\
\hline PhD & 8.8 \\
\hline Dk/Da & 0.0 \\
\hline
\end{tabular}

\begin{tabular}{|l|l|}
\hline \multicolumn{2}{|c|}{ Children } \\
\hline Yes. Some under 13 years old & 37.1 \\
\hline Yes. All over 13 years old & 15.5 \\
\hline No & 47.4 \\
\hline
\end{tabular}

\begin{tabular}{|l|r|}
\hline \multicolumn{2}{|c|}{ Occupation } \\
\hline Housewife & 5.2 \\
\hline Student & 8.8 \\
\hline Retired & 1.6 \\
\hline Unemployed & 3.6 \\
\hline Working & 66.1 \\
\hline Working and studying & 13.9 \\
\hline Dk/Da & 0.8 \\
\hline
\end{tabular}

\begin{tabular}{|l|l|}
\hline \multicolumn{2}{|c|}{ Female children } \\
\hline Yes & 68.9 \\
\hline No & 31.1 \\
\hline
\end{tabular}

\begin{tabular}{|l|r|}
\hline \multicolumn{2}{|c|}{ Net monthly household income } \\
\hline Less than $€ 1,000$ & 9.2 \\
\hline$€ 1,000-1,999$ & 21.1 \\
\hline$€ 2,000-2,999$ & 13.6 \\
\hline$€ 3,000-4,999$ & 17.1 \\
\hline$€ 5,000-8,000$ & 15.5 \\
\hline More than $€ 8,000$ & 6.8 \\
\hline Dk/da & 16.7 \\
\hline
\end{tabular}

Table 2. Perceived attributes of images of girls studied

\begin{tabular}{|c|c|}
\hline \multirow{3}{*}{ Competence attributes } & She looks careful and tidy \\
\hline & She looks very responsible \\
\hline & She looks hard-working \\
\hline Intelligence attribute & She looks very intelligent \\
\hline Decision attribute & She looks very determined \\
\hline \multirow{6}{*}{ Sociability attributes } & She looks very nice \\
\hline & She looks very kind \\
\hline & $\begin{array}{l}\text { She looks like she mocks her friends and } \\
\text { companions }\end{array}$ \\
\hline & She looks very friendly \\
\hline & She looks very shy \\
\hline & $\begin{array}{l}\text { If I had a daughter, a niece, a } \\
\text { granddaughter..., of her age, I would really } \\
\text { like her to be her friend }\end{array}$ \\
\hline \multirow{2}{*}{ Decorum attributes } & She looks very decorous \\
\hline & She looks very brazen \\
\hline \multirow{4}{*}{$\begin{array}{l}\text { Physical appearance } \\
\text { and style attributes }\end{array}$} & $\begin{array}{l}\text { Her clothes seem very appropriate for her } \\
\text { age }\end{array}$ \\
\hline & She's beautiful \\
\hline & I love her look \\
\hline & She looks plain \\
\hline
\end{tabular}

characteristics of girls under 10 years of age in terms of competence, intelligence, sociability, decorum, physical appearance, and clothing. For this purpose, four in-depth interviews were carried out (prior to conducting the survey and the drawing up of the questionnaire) with professionals who are experts in child education and with mothers of girls. All attributes have been evaluated according to a 7-point Likert scale (1 = Totally disagree; 7 = Totally agree) ensuring a high reliability of the final scale (Cronbach's $\alpha=0.835$ )

- A 5 level interval scale was used to measure the media consumption of the respondents ( $1=$ Never or almost never, 5 = Very frequently).

- To measure the degree of self-objectification of the respondents, McKinley and Hyde's (1996) multiple scale was developed to measure this construct with 7 levels ( 1 = Totally disagree; 7 = Totally agree).

- To measure the religiosity of the respondents, an interval scale of 5 levels has been used ( $1=$ Zero; $5=$ Very).

\section{Materials}

The study focused on Instagram, the social network, for the following reasons:

- It was the first social network created specifically to share photographs with all its users. 


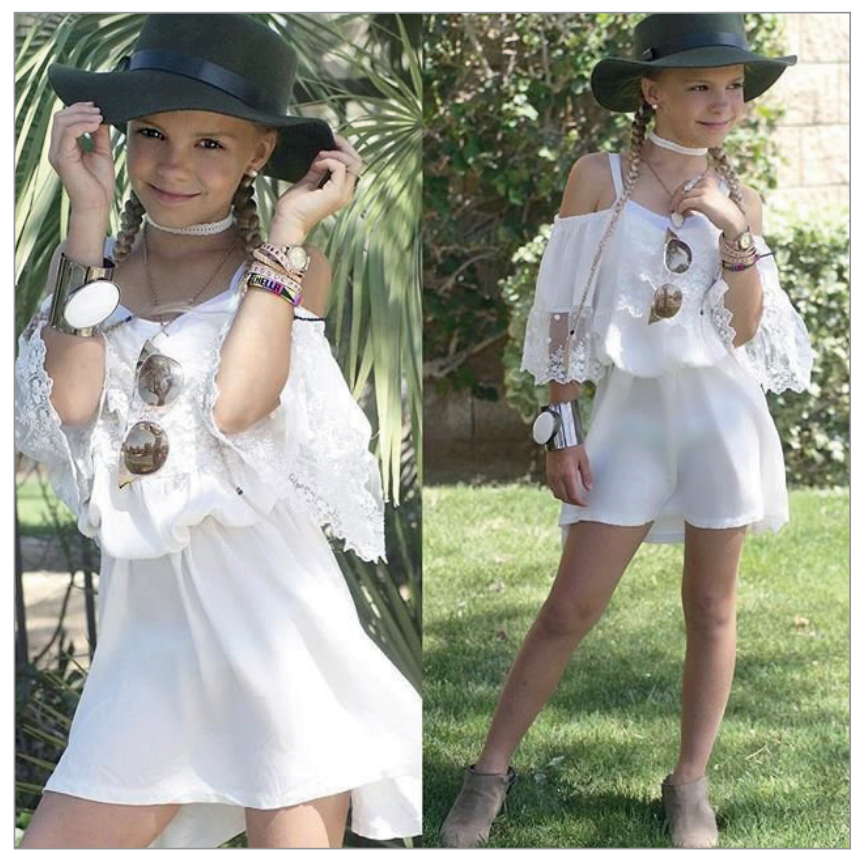

Image 1. Sexualized image

Photos used in the present research

- It is the best known, most valued, most preferred, and most used social network of its kind $(I A B, 2016)$.

Two photographs were selected from two different Instagram accounts:

- one belonging to a girl with a very obviously sexualized appearance,

- and another one from a girl with a completely non-sexualized appearance.

The photographs were selected as follows: the authors opened an Instagram account to use in this study and they searched (from May 1 to 15, 2016) for photographs related to children's fashion in general and "mini-me" fashion in particular. Subsequently, on May 16, 2016, the 10 most popular accounts in girls and fashion trends for girls' categories were selected (excluding children's fashion brands' accounts). The 60 first photographs of that day were selected from of each of these accounts ${ }^{3}$. Subsequently, on May 16, 2016, the 10 most popular accounts in girls and fashion trends for girls' categories were selected (excluding children's fashion brands' accounts). The 60 first photographs of that day were selected from of each of these accounts.

We analyzed the 600 photographs chosen in order to select the two definitive ones according to the following criteria:

- we eliminated all the photographs of girls obviously under 5 and over 12 years old;

- also discarded those in which the girls appeared with sunglasses on ${ }^{4}$ (which made it impossible to see their eyes), those showing adult accessories (especially bags) that made them look extravagant, and/or fall-winter looks were discarded ${ }^{5}$. Then, in order to select the photograph of a girl with a sexualized appearance, photos of girls showing at least 5 sexualizing items according to the Graff, Murnen, and Smolak (2012) scale were chosen and finally the one with the most followers was selected.

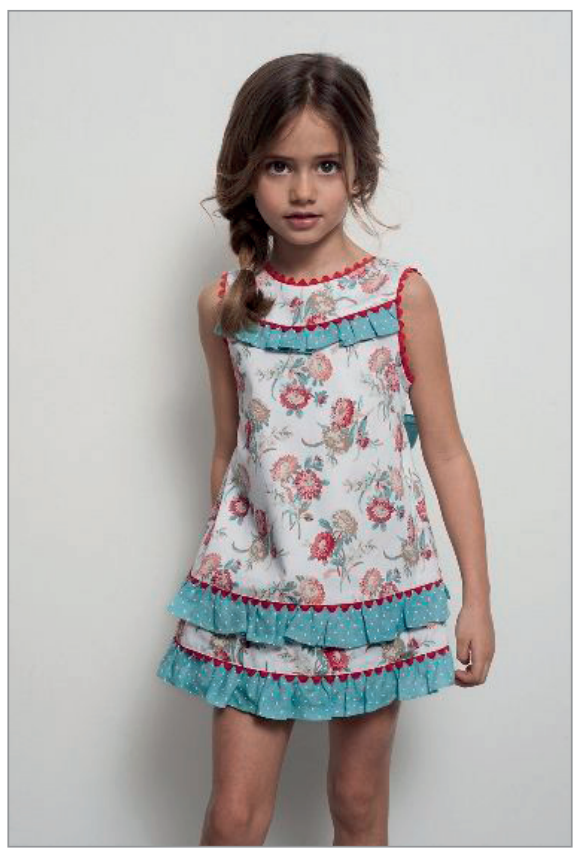

Image 2. Non-sexualized image

In order to select the photograph of the girl with the nonsexualized appearance a new search on Instagram had to be carried out since the previous one did not produce any photographs in which a girl did not show any of the sexual characteristics identified by Graff, Murnen, and Smolak (2012).

Thus, on May 20, 2016, the first five accounts of children's fashion brands suggested by Instagram were chosen by searching for "child fashion", and the first 60 photographs of the day were selected on each account. Of the 300 resulting photographs, all male children were discarded; girls aged the same as that of the girl whose image was sexualized were selected and from those the ones which did not show any of the sexual characteristics identified by Graff, Murnen, and Smolak (2012) remained. Finally, the photograph with the most likes was chosen.

The sexualization of girls in social networks leads to adults assessing them as less competent, intelligent, sociable, and decorous than non-sexualized images

\section{Results}

The analysis of the correlations between the variables related to the perceptions of the sexualized image of the girl by the adults studied and those related to the characteristics of the latter in terms of their media consumption (Table 3), level of self-objectification and religiosity (Table 4), has shown the existence of significant correlations between many of them, which allows the first three hypotheses to be accepted.

Specifically, in terms of $\mathrm{H} 1$, cosmetics and beauty pages and sections on social networks and gossip magazines have been shown to be the media that most influence subjects' 
perceptions followed by gossip websites, fashion pages on social networks and finally, fashion and beauty magazines. Thus, the more one consumes of each of these types of media, the more the perception of sexualized girls improves, that is, the more these images are accepted.

Specifically, the two variables most sensitive to media consumption are "I love her look" and "If I had a daughter, niece, granddaughter... her age, I would really like her to be her friend."

Furthermore, the social network which most influences the perceptions analyzed is Instagram, followed by Facebook, Snapchat, and Pinterest (Table 3).

As for $\mathrm{H} 2$, it has been verified (see Table 4) that, in general, the greater the degree of self-objectification of a subject, the less negative their perceptions of the image that sexualizes the girl. In this regard, the variables most sensitive to self-objectification are "she looks very determined", "she looks like she mocks her friends and companions" and "she looks very responsible".

In relation to $\mathrm{H} 3$, it is indisputable that the religiosity of the respondents is closely linked to their perceptions of the ima- ge that sexualizes the girl (see Table 4), so that the variables most sensitive to religiosity are "she looks very decorous", "if I had a daughter, a niece, a granddaughter ... of her age, I would really like her to be her friend", "I love her look", "she looks very brazen" and "she looks very responsible".

The use of social networks to spread sexualized photographs of girls damages and undermines the general image that society has of childhood

Finally, with respect to $\mathrm{H} 4$, a t-test of means has been performed to compare the media corresponding to the perceptions of the image that sexualizes the girl by all the respondents with those of the non-sexualized girl. The results are clear (see Graph 1); in almost all attributes of the perceived image of both girls, the image that sexualizes the girl is viewed more negatively than the non-sexualized one with the differences between both evaluations being statistically significant.

Table 3. Significant correlations between the sexualized image (Image 1), media consumption, and use of social media

\begin{tabular}{|c|c|c|c|c|c|c|c|c|c|c|}
\hline & & \multicolumn{9}{|c|}{ Media consumed and use of social networks } \\
\hline \multicolumn{2}{|c|}{$\begin{array}{l}\text { Perceptions of the sexualized } \\
\text { image of the girl }\end{array}$} & $\begin{array}{c}\text { Fashion } \\
\text { and } \\
\text { beauty }\end{array}$ & $\begin{array}{c}\text { Gossip } \\
\text { magazines }\end{array}$ & $\begin{array}{l}\text { Fashion } \\
\text { accounts } \\
\text { on social }\end{array}$ & $\begin{array}{l}\text { Beauty } \\
\text { accounts } \\
\text { on social }\end{array}$ & $\begin{array}{l}\text { Internet } \\
\text { gossip }\end{array}$ & $\begin{array}{l}\text { Instagram } \\
\text { user }\end{array}$ & $\begin{array}{l}\text { Facebook } \\
\text { user }\end{array}$ & $\begin{array}{l}\text { Pinterest } \\
\text { user }\end{array}$ & $\begin{array}{l}\text { Snapchat } \\
\text { user }\end{array}$ \\
\hline \multirow{2}{*}{$\begin{array}{l}\text { Her clothes } \\
\text { seem very } \\
\text { appropriate for } \\
\text { her age }\end{array}$} & Correlation & 0.077 & $0.168^{* *}$ & 0.032 & $0.175^{* *}$ & 0.064 & 0.073 & 0.105 & 0.092 & 0.112 \\
\hline & Sig. (bilateral) & 0.224 & 0.008 & 0.614 & 0.005 & 0.310 & 0.246 & 0.097 & 0.145 & 0.077 \\
\hline \multirow{2}{*}{$\begin{array}{l}\text { She looks very } \\
\text { nice }\end{array}$} & Correlation & 0.102 & 0.066 & 0.121 & $0.125^{*}$ & 0.025 & 0.093 & 0.097 & -0.011 & 0.078 \\
\hline & Sig. (bilateral) & 0.107 & 0.294 & 0.056 & 0.048 & 0.691 & 0.142 & 0.127 & 0.858 & 0.216 \\
\hline \multirow{2}{*}{$\begin{array}{l}\text { She looks very } \\
\text { decorous }\end{array}$} & Correlation & 0.040 & 0.013 & 0.110 & $0.160^{*}$ & -0.011 & $0.146^{*}$ & $0.177^{* *}$ & 0.023 & $0.167^{* *}$ \\
\hline & Sig. (bilateral) & 0.526 & 0.836 & 0.082 & 0.011 & 0.865 & 0.021 & 0.005 & 0.715 & 0.008 \\
\hline \multirow{2}{*}{ I love her look } & Correlation & $0.128^{*}$ & $0.155^{*}$ & $0.236^{* *}$ & $0.210^{* *}$ & $0.246^{* *}$ & $0.137^{*}$ & $0.192^{* *}$ & 0.048 & $0.218^{* *}$ \\
\hline & Sig. (bilateral) & 0.042 & 0.014 & 0.000 & 0.001 & 0.000 & 0.030 & 0.002 & 0.452 & 0.000 \\
\hline \multirow{2}{*}{$\begin{array}{l}\text { She looks very } \\
\text { brazen }\end{array}$} & Correlation & 0.018 & -0.041 & -0.086 & -0.101 & -0.041 & $-0.144^{*}$ & -0.096 & -0.042 & -0.049 \\
\hline & Sig. (bilateral) & 0.772 & 0.518 & 0.176 & 0.110 & 0.515 & 0.023 & 0.127 & 0.510 & 0.438 \\
\hline \multirow{2}{*}{ She looks plain } & Correlation & -0.030 & -0.116 & 0.078 & 0.025 & -0.068 & $0.157^{*}$ & 0.116 & 0.081 & 0.091 \\
\hline & Sig. (bilateral) & 0.636 & 0.067 & 0.220 & 0.692 & 0.286 & 0.013 & 0.067 & 0.200 & 0.152 \\
\hline \multirow{2}{*}{$\begin{array}{l}\text { If I had a } \\
\text { daughter, a } \\
\text { niece, a grand- } \\
\text { daughter..., of } \\
\text { her age, I would } \\
\text { really like her to } \\
\text { be her friend }\end{array}$} & Correlation & $0.190^{* *}$ & 0.079 & $0.142^{*}$ & $0.155^{*}$ & $0.129^{*}$ & 0.062 & 0.109 & 0.080 & 0.085 \\
\hline & Sig. (bilateral) & 0.003 & 0.212 & 0.024 & 0.014 & 0.041 & 0.332 & 0.084 & 0.209 & 0.181 \\
\hline \multirow{2}{*}{$\begin{array}{l}\text { She looks hard- } \\
\text { working }\end{array}$} & Correlation & 0.068 & $-0.127^{*}$ & -0.025 & 0.054 & -0.100 & 0.019 & 0.060 & $0.164^{* *}$ & 0.058 \\
\hline & Sig. (bilateral) & 0.286 & 0.044 & 0.697 & 0.391 & 0.115 & 0.759 & 0.345 & 0.009 & 0.363 \\
\hline
\end{tabular}

* Correlation is significant at the 0.05 level (two-tailed).

** Correlation is significant at the 0.01 level (two-tailed). 
Table 4. Significant correlations between perceptions of sexualized girls, self-objectification, and religiosity

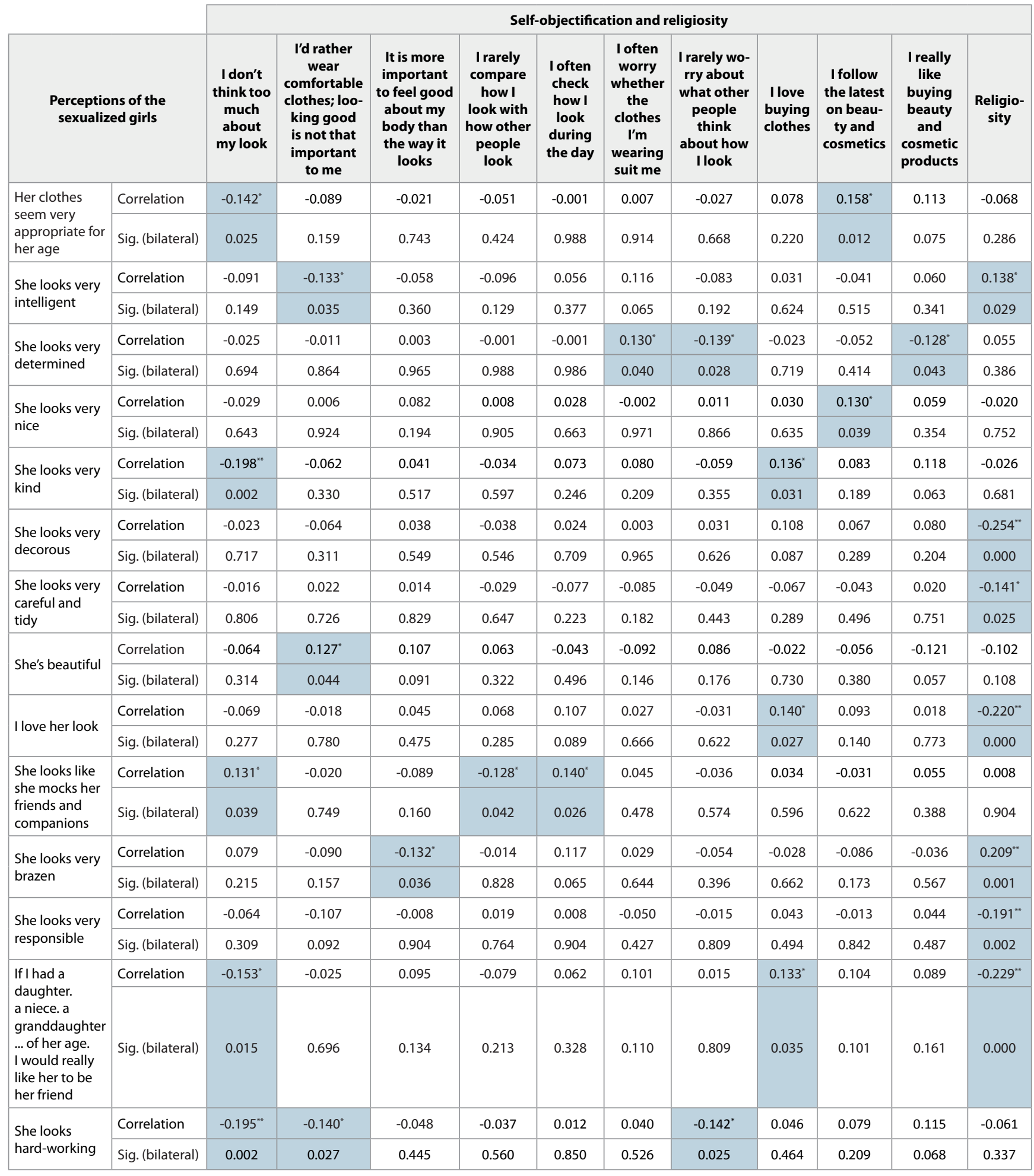

*. Correlation is significant at the 0.05 level (two-tailed)

**. Correlation is significant at the 0.01 level (two-tailed)

The image that sexualizes the girl is perceived not only as being significantly less competent, intelligent, sociable, and decorous than the non-sexualized one, but her clothes are also considered to be very inappropriate for her age and her look produces a very negative response. And this is true for all those studied, regardless of their media consumption, their degree of self-objectification, and their religiosity, although for those who consume more media, have a more objectified vision of themselves or who consider themselves less religious or not religious at all, the differences in their perceptions of the two girls are less marked than for the others. The biggest differences between the perceptions of both girls are given in the following variables: "her clothes seem very appropriate for her age", "I love her look", "if I had a daughter, niece, granddaughter ... her age, I would very much like her to be her friend" and "seems very bra- 


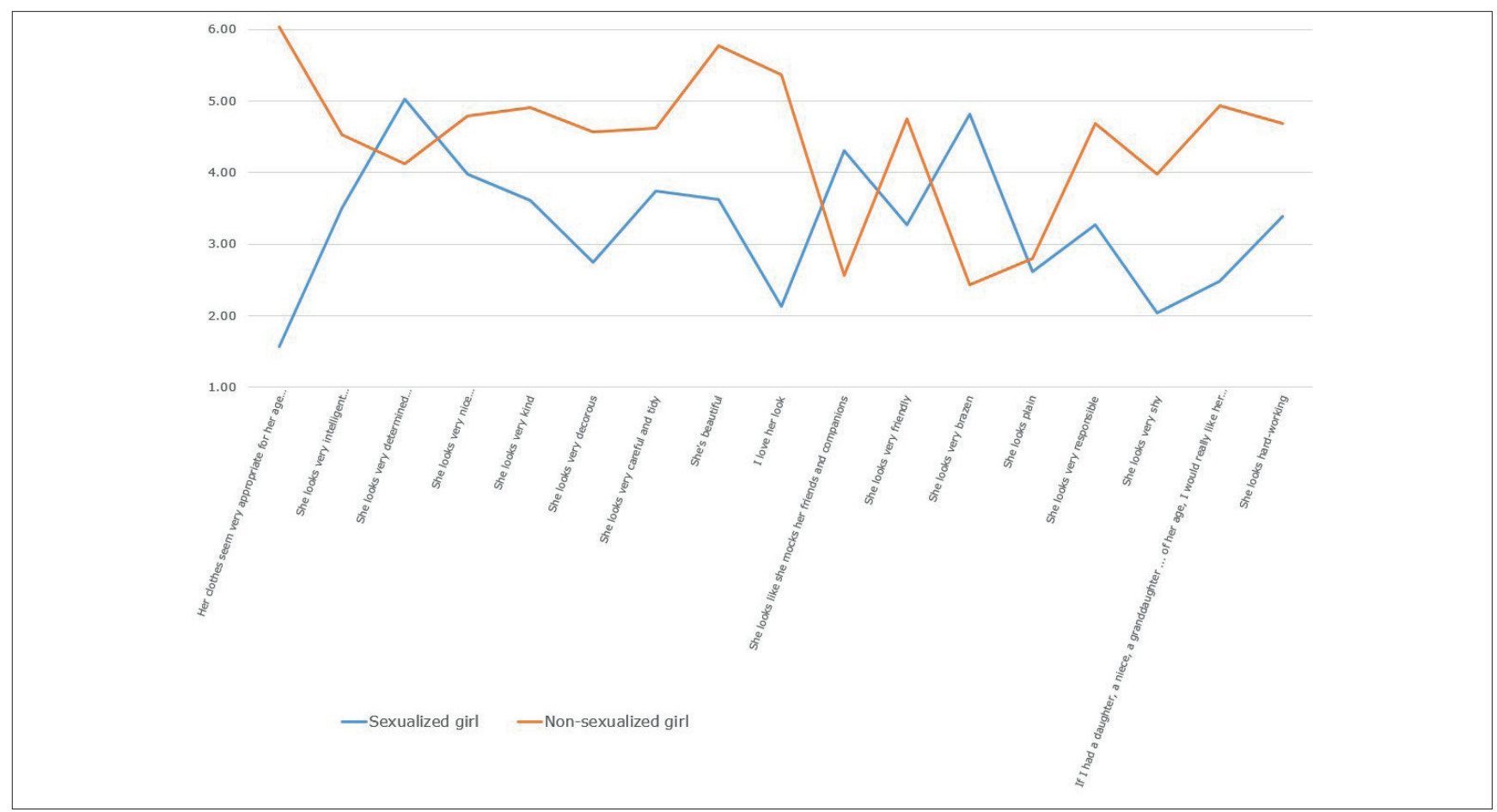

Graph 1. Perceived image of girls' profile

zen", with the evaluations of the image that sexualizes the girl being negative and those of the image that does not sexualize the girl, positive.

\section{Discussion and conclusion}

Leaving aside the question of whether the sexualization of children is good or bad in itself, the results of this study show the spread of photographs that sexualize girls through social networks is harmful for girls, when compared to images of girls that have not been sexualized. It is clear that this sexualization of girls results in adults having negative perceptions about the girls' intellectual, social, and moral capacities. Thus, we should be warned that the use of social networks to spread such photographs damages and undermines the general image that society has of childhood. And this warning should alert parents (especially mothers), who are the main creators and promoters of profiles that sexualize girls in social networks.

The media consumption, self-objectification, and religiosity of adults are factors related to the perception of sexualized images of girls in social networks

Furthermore, it has been verified that the media consumption, self-objectification, and religiosity of adults are factors related to the perceived image of sexualized girls in social networks. We should therefore reflect on the necessity to design activities to promote a positive vision of child sexuality (as proposed by Egan and Hawkes, 2008) or, on the contrary, reinforce awareness of the negative effects of the sexualization of children in social networks and increase the protection of children in the context of the spread of their photographs on social networks.

Finally, since this research has focused on the Instagram social network and on the perceptions that adults have of girls, it would be interesting to extend the study to other social networks as well as to perceptions regarding boys to verify whether, in both cases, the results are consistent with those presented here.

\section{Notes}

1. We talk about "objectification" to refer to the person's objectified vision. That is, to the consideration of the person as a thing or object. Bartky (1990) speaks of "sexual objectification" of women when they are considered as mere bodies specially conceived for the pleasure of others.

2. We use the expression "self- objectification" to refer to a person's objectified vision of self. The "theory of objectification" (Fredrickson; Roberts, 1997) proposes that repeated exposure to experiences that objectify leads to a "self- objectification" that makes girls and women internalize messages that sexually objectify them and that lead them to have a vision of their own bodies as objects that are evaluated according to limited standards of beauty.

3. Since Instagram makes recommendations to its users based on the searches made by them, we carried out searches that generated recommendations on the profiles of the most relevant girls who had more followers.

4. Since the characteristics of girls related to their competence, intelligence, sociability, and decorum were to be assessed in the survey, it was considered necessary for the girls' face and eyes not to be hidden. As Orozco (2005) points out, the eyes and hands are the most expressive and 
differentiating elements of the character of the people. Another study (Spry, 2012) on the sexualization of girls in Japanese cartoons emphasizes the role of the eyes in their ability to represent emotional states.

5. The fall-winter "looks" were discarded so that they did not generate rejection as inappropriate since the survey was to be carried out during the month of June.

\section{Acknowledgements}

This study is part of the Program of activities on digital vulnerability (Provuldig), financed by the Community of Madrid (Ministry of Education, Youth and Sport, Ref. S2015 / HUM3434).

\section{Bibliography}

Acosta, Corinna (2014). "4 casos en los que la publicidad ha sexualizado a la infancia". ExpokNews. Comunicación de sustentabilidad y RSE, 23 diciembre.

http://www.expoknews.com/4-casos-en-los-que-lapublicidad-ha-sexualizado-a-la-infancia

AEPD (2008). Agencia Española de Protección de Datos. Guía de recomendaciones para que padres e hijos naveguen de forma segura.

Albéniz, Myriam Z. (2014). "El auge de la erotización de la infancia". La provincia, 5 junio.

http://www.laprovincia.es/opinion/2014/06/06/augeerotizacion-infancia/613003.html

American Psychological Association (2007). Task force on the sexualization of girls. Report of the APA task force on the sexualization of girls.

http://www.apa.org/pi/women/programs/girls/index.aspx

Arteaga-Villamil, María-Dolores (2010). "El show infantil: la construcción de una hiper-feminidad sexual púber en el marco del capitalismo". En: Macip-Ríos, Ricardo-Francisco; Carreras-Sendra, Natatxa. Perversión y duplicidad: en torno a la producción de subjetividades del cuerpo político en México. Puebla: Benemérita Universidad Autónoma de Puebla, Instituto de Ciencias Sociales y Humanidades Alfonso Vélez Pliego, pp. 87-136. ISBN: 9786074872309

https://www.academia.edu/4807598/La_construcción_de_ una_hiper-_feminidad_sexual_púber

Bailey, Reg (2011). Letting children be children: Report of an independent review of the commercialisation and sexualisation of childhood. Great Britain: The Stationery Office. ISBN: 9780101807821

https://goo.gl/SuWz9p

Bartky, Sandra-Lee (1990). Femininity and domination: Studies in the phenomenology of oppression. Great Britain: Psychology Press. ISBN: 978041590184

Cikara, Mina; Eberhardt, Jennifer L.; Fiske, Susan T. (2011). "From agents to objects: Sexist attitudes and neural responses to sexualized targets". Journal of cognitive neuroscience, v. 23, n. 3, pp. 540-551.

https://www.ncbi.nlm.nih.gov/pmc/articles/PMC3801174

https://doi.org/10.1162/jocn.2010.21497

Corisco, María; Pérez-Hernando, Cristina (2014). “¿A quién imitan las niñas de hoy en día? S Moda El país, 9 marzo. http://smoda.elpais.com/moda/a-quien-imitan-las-ninasde-hoy-en-dia

Daniels, Elizabeth A. (2012). "Sexy versus strong: What girls and women think of female athletes". Journal of applied developmental psychology, v. 33, n. 2, pp. 79-90. https://doi.org/10.1016/j.appdev.2011.12.002

Daniels, Elizabeth A.; Zurbriggen, Eileen L. (2016). “The price of sexy: Viewers' perceptions of a sexualized versus nonsexualized Facebook profile photograph". Psychology of popular media culture, v. 5, n. 1, pp. 2-14.

https://doi.org/10.1037/ppm0000048

Dietrich, Timo; Rundle-Thiele, Sharyn; Schuster, Lisa; Drennan, Judy; Russell-Bennett, Rebekah; Leo, Cheryl; Gullo, Matthew J.; Connor, Jason P. (2015). "Differential segmentation responses to an alcohol social marketing program". Addictive behaviors, v. 49, pp. 68-77.

https://goo.gl/kFYw5Y

https://doi.org/10.1016/j.addbeh.2015.05.010

Egan, R. Danielle; Hawkes, Gail L. (2008). “Endangered girls and incendiary objects: Unpacking the discourse on sexualization". Sexuality \& culture, v. 12, n. 4, pp. 291-311.

https://goo.gl/uBHVrX

https://doi.org/10.1007/s12119-008-9036-8

Euromonitor International (2015). Micro fashion: Trends in childrenswear. Global briefing. Euromonitor International. http://www.euromonitor.com/micro-fashion-trends-inchildrenswear/report

Fominaya, Carlota; Peraita, Laura (2013). “Motivos por los que no debes colgar fotos de tus hijos por las redes sociales". ABC.es, 4 noviembre.

http://www.abc.es/familia-padres-hijos/20131014/abcihijos-fotos-facebook-201310101706.html

Fredrickson, Barbara L.; Roberts, Tomi-Ann (1997). “Objectification theory: Toward understanding women's lived experiences and mental health risks". Psychology of women quarterly, v. 21, n. 2, pp. 173-206.

http://www.sanchezlab.com/pdfs/FredricksonRoberts.pdf https://doi.org/10.1111/j.1471-6402.1997.tb00108.x

Goodin, Samantha M.; Van-Denburg, Alyssa; Murnen, Sarah K.; Smolak, Linda (2011). "'Putting on' sexiness: A content analysis of the presence of sexualizing characteristics in girls' clothing". Sex roles, v. 65, n. 1, pp. 1-12.

http://web.mit.edu/end_violence/docs/sexualizing-girlsclothing.pdf

https://doi.org/10.1007/s11199-011-9966-8

Graff, Kaitlin A.; Murnen, Sarah K.; Krause, Anna K. (2013). "Low-cut shirts and high-heeled shoes: Increased sexualization across time in magazine depictions of girls". Sex roles, v. 69, n. 11, pp. 571-582.

https://goo.gl/30yLDX

https://doi.org/10.1007/s11199-013-0321-0

Graff, Kaitlin A.; Murnen, Sarah K.; Smolak, Linda (2012). "Too sexualized to be taken seriously? Perceptions of a girl in childlike vs. sexualizing clothing". Sex roles, v. 66, n. 11, pp. 764-775. 
https://goo.gl/rOL1Ao

https://doi.org/10.1007/s11199-012-0145-3

Gurung, Regan A. R.; Chrouser, Carly J. (2007). “Predicting objectification: Do provocative clothing and observer characteristics matter?". Sex roles, v. 57, n. 1-2, pp. 91-99.

https://goo.gl/GE2JcF

https://doi.org/10.1007/s11199-007-9219-z

Hall, P. Cougar; West, Joshua H.; Mclntyre, Emily (2012). "Female self-sexualization in MySpace.com personal profile photographs". Sexuality \& culture, v. 16, n. 1, pp. 1-16. https://goo.gl/95TGn3 https://doi.org/10.1007/s12119-011-9095-0

Interactive Advertising Bureau - IAB (2016). Estudio anual de redes sociales 2016.

http://www.iabspain.net/redes-sociales

ICMedianet Publicaciones (2011). La protección del menor tras la ley general de la comunicación audiovisual: Perspectivas y retos. ISBN: 9788469540749

https://goo.gl/rllBOa

Lamb, Sharon (2009). "Media effects and the sexualization of girls". Sex roles, v. 60, n. 5, pp. 439-441.

https://www.researchgate.net/publication/226753619_

Media_Effects_and_the_Sexualization_of_Girls

https://doi.org/10.1007/s11199-008-9536-x

Lerum, Kari; Dworkin, Shari L. (2009). “'Bad girls rule’: An interdisciplinary feminist commentary on the report of the APA Task force on the sexualization of girls". The journal of sex research, v. 46, n. 4, pp. 250-263.

http://faculty.washington.edu/lerum/Bad\%20Girls\%20 Rule.pdf

https://doi.org/10.1080/00224490903079542

Llovet-Rodríguez, Carmen; Díaz-Bustamante, Mónica; Patiño-Alves, Beatriz (2016). "The sexualization of children through advertising, fashion brands and media". Prisma social, n. especial 1, pp. 156-189.

https://goo.gl/4AlkBn

Machia, Marty; Lamb, Sharon (2015) (artículo online desde 2009). "Sexualized innocence: Effects of magazine ads portraying adult women as sexy little girls". Journal of media psychology, v. 21, n. 1, pp. 15-24.

https://goo.gl/9PjVYB

https://doi.org/10.1027/1864-1105.21.1.15

McCroskey, James C.; McCain, Thomas A. (1974). "The measurement of interpersonal attraction". Speech monographs, v. 41, n. 3, pp. 261-266.

http://www.jamescmccroskey.com/publications/057.pdf https://doi.org/10.1080/03637757409375845

McKinley, Nita-Mary; Hyde, Janet-Shibley (1996). "The objectified body consciousness scale. Development and valida- tion". Psychology of women quarterly, v. 20, n. 2, pp. 181-215. https://goo.gl/b1vUdo

https://doi.org/10.1111/j.1471-6402.1996.tb00467.x

Milwood, Andrea (2006). Harm and offence in media content: A review of evidence. Bristol. ISBN: 9781841502380

http://eprints.Ise.ac.uk/49000/1/Livingstone_Harm_ offence_media_2009.pdf

Molina, Violeta (2015). "Y cuando los menores de las fotos de Facebook e Instagram crezcan, ¿qué?". El mundo, 20 septiembre.

http://www.elmundo.es/tecnologia/2015/09/20/55fe6e2b 46163f03638b456d.html

Orozco, Antonio (2005). "El pudor: defensa de la dignidad personal". Arvo.net, 23 julio.

http://arvo.net/el-valor-de-la-sexualidad/el-valor-de-lasexualidad/gmx-niv380-con16006.htm

Ortiz-Tardio, Joaquín (2008). "El niño, los medios y la publicidad". Vox paediatrica, v. 16, n. 1, pp. 39-43.

http://spaoyex.es/sites/default/files/pdf/Noxpaed16.1pags39-43. $p d f$

Rodríguez, Alejandra (2007). "La erotización de la infancia causa alteraciones físicas y psíquicas a medio y largo plazo". Salud. El mundo, 17 marzo.

http://www.elmundo.es/suplementos/salud/2007/702/1174086011. html

Schuster, Lisa; Kubacki, Krzysztof; Rundle-Thiele, Sharyn (2015). “A theoretical approach to segmenting children's walking behaviour". Young consumers, v. 16, n. 2, pp. 159-171.

http://eprints.qut.edu.au/82117/3/82117.pdf https://doi.org/10.1108/YC-07-2014-00461

Serrano, Beatriz (2013). "Hipersexualización de la infancia: cuando los niños crecen antes de tiempo". Bebés y más, 8 enero.

https://goo.gl/f7Z6c

Spry, Damien (2012). “Make her skinnier, make her curvier: Sexualised girlhood in Japanese cartoons". En: Götz, Maya; Lemish, Dafna. Sexy girls, heroes and funny losers. Germany: Peter Lang, pp. 91-106. ISBN: 9783631633199 https://goo.gl/NhHc2G

Starr, Christine; Ferguson, Gail M. (2012). "Sexy dolls, sexy grade-schoolers? Media \& maternal influences on young girls' self-sexualization". Sex roles, v. 67, n. 7, pp. 463-476. https://goo.gl/TzHI1N https://doi.org/10.1007/s11199-012-0183-x

Wills, Jane; Crichton, Nicola; Lorenc, Ava; Kelly, Muireann (2014). "Using population segmentation to inform local obesity strategy in England". Health promotion international, v. 30, n. 3, pp. 658-666.

https://doi.org/10.1093/heapro/dau004 